\title{
Positioning of light shelves to enhance daylight illuminance in
} office rooms

\author{
Badri Narayan Mohapatra ${ }^{1}$, M. Ravi Kumar ${ }^{2}$, Sushanta K. Mandal ${ }^{3}$ \\ ${ }^{1}$ Department of Electronics \& Communication, CUTM, India \\ ${ }^{2}$ Department of Electronics \& Communication, Mnit, India \\ ${ }^{3}$ Department of Electronics \& Communication Engineering, Sharda University, India
}

\begin{tabular}{l}
\hline Article Info \\
\hline Article history: \\
Received Dec 30, 2018 \\
Revised Jan 21, 2019 \\
Accepted Mar 10, 2019 \\
\hline Keywords: \\
Daylight simulation \\
Daylighting \\
Dialux \\
Illuminance \\
Light shelf \\
Sunlight \\
\hline
\end{tabular}

\begin{abstract}
This paper aims to improve daylighting by using light shelves. Horizontal light shelf enhances the illuminance in office room interior. By tilting external light shelf more illuminance can be achieved. For uniformity of illuminance tilt able light shelf is the best choice instead of horizontal light shelf. The performance of light shelves was examined through simulations on DIALux and compared with experimental values obtained from a prototype. Substantial improvement in illuminance is obtained in the experimental studies with tilted light shelves on the prototype.
\end{abstract}

Corresponding Author:

Badri Narayan Mohapatra,

Department Of Electronics \& Communication,

CUTM, Paralakhemundi, 761211, India.

Email: badri1.mohapatra@gmail.com

Copyright $@ 2019$ Institute of Advanced Engineering and Science. All rights reserved.

\section{INTRODUCTION}

Electric lighting can be replaced by daylight for most of the typical working day in most building types if the building allows daylight to reach most of the interior. However, it is difficult to achieve daylighting in most office buildings by simply applying windows around the perimeter of the building for side-lighting. Even when these windows are from wall to wall, this approach is unable to supply daylight to large portions of a building especially deeper into rear spaces away from the windows. Light tubes, pipes and fibers can be used to transport light to interior areas. Another way of enhancing daylight can be with the help of light shelves. A light shelf usually palced above eye height. It can be internal and/ or external to the interior space. The internal light shelves block direct sunlight from the window area above the shelf while at the same time the exterior light self shades lower portion of the window. Energy consumption of buildings can be minimized by using light shelves.

Usually two different methods were employed for the study of daylighting performance. One of these is the empirical study using physical model with field measurement [1-2] and the other one is by using simulation software [3-4]. A light shelf is a horizontal plate made of light-colored and reflective materials that reflects daylight. It is positioned in the upper half of the window and above the height of human eye. Due to this near the window light severity decreseas and light penetration depth increases. For better performance the light shelf is accompanied with shading or an external shelf. [5]. Meresi focuses on evaluating daylight performance of light shelves combined with external blinds in south-facing classrooms of Athens [6]. A light shelf to provide shading to the lower part of the windows leading to reduced cooling loads in summer is discussed in [7]. According to [14], curved light shelf could improve the daylight level by $10 \%$ compared to a horizontal lightshelf. To eliminate the effect of absorbing solar heat, shading systems should be located in the 
external part of the window. Both internal and external light shelves with slats are equipped to improve daylighting performance while allowing direct sun [9]. Side-lighting systems are designed to avoid an unequal distribution of natural light which may occur through the use of traditional lateral windows [10]. Light shelves affect the architectural and structural design of a building and must be considered at the start of the design phase as they require a relatively high roof in order to function efficiently.

This article focuses on light shelves which guide daylight uniformly to the room. This work mainly relates to investigate light shelf influence of selected design parameters based on simulation as well as experiment on prototype model.

The paper outline is given as follows. Section 1 presents the introduction to light shelves as a passive architectural element. Section 2 describes the main objective and the context of this research. Section 3 describes about adaption system of light shelf. Section 4 describes the model parameters value used in simulation as well as simulation settings and it's process. Different cases on variation with lightshelf is discussed in Section 5. The article concludes with brief concluding remarks and future proposed work in Section 6. Different possible positions of light shelf for redirecting light into a room as shown in Figure 1.

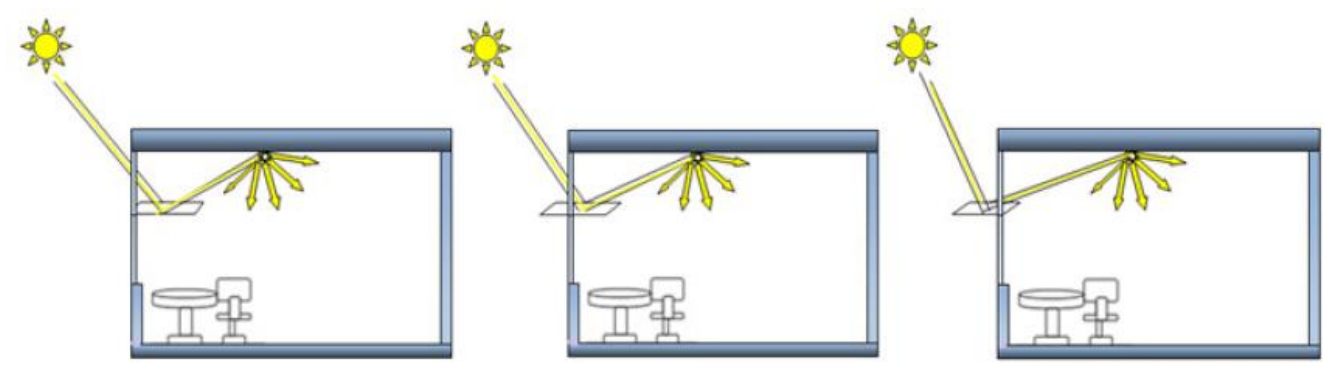

Figure 1. Different possible positions of light shelf for redirecting light into a room

\section{OBJECTIVE}

Due to increasing awareness about environmental issues, studies focusing on reducing and saving energy are being carried out in many fields. To address this issue, the light shelf system is one among various systems that is being studied actively because it reduces the indoor lighting energy consumption in buildings and brings natural light deep into indoors, creating a balance between indoor illumination and the saving of lighting energy. Light shelves are natural lighting systems, the use of which has been highlighted in various studies as a suitable approach for reducing lighting energy consumption.

Daylighting would be effective when daylight falls on windows throughout the day. Utilizing a light shelf is a common strategy for enabling daylight transmission while controlling direct sun and discomfort glare to maintain occupant comfort. It is difficult for most high-rise office buildings to achieve daylight by simply using windows around the perimeter of the side lit building. Even when these side windows are from wall to wall, this strategy can hardly supply sufficient sunlight deep into the space. New daylighting strategies are needed for better daylight utilization in office buildings, such as increased daylight penetration and uniformity. Utilizing a light shelf is such a strategy for enabling daylight transmission while controlling direct sun and discomfort glare to maintain occupant comfort.

This light shelf creates one strong horizontal line, breaking the building into two parts. The lower surface of the light shelf is made of a matte finish while the upper surface is composed of specular mirror panels, reflecting sunshine to building. A light shelf is an easy solution. Installing a light weight light shelf has minimal requirements/ effects on the buildings structure and existing envelope.

A light shelf is not always a simple horizontal slab. It could be of different shapes, sizes, materials, and mounted at different positions.

Traditional windows, as the major source of daylight, have a common problem which is uneven distribution of daylight in the room. Several innovative daylighting systems such as light shelves, fixed and movable reflective louvers, reflective sills, prismatic glazing, light pipes, etc., have been developed to address this problem [11]. Consequently, light shelves are often proposed to help reduce glare issues, providing better illumination distribution, and increasing the homogeneity of daylight distribution into the spaces [12]. Light shelves reduce glare issues while increasing the daylighting penetration into the space $[13,14]$. Exterior shelves are more effective shading devices than interior shelves. A combination of exterior and interior shading devices will work best in providing an even illumination gradient [15]. 
Researchers also think for optimize way to use PV system for building [16] as well as some novel approach of controlling PV system [17]. But for this world energy scrace [18] and fresh water [19] are much needed. For energy saving solar tracking [20] and room luminance measurement is also important factor [21].

The objectives of this article can be summarized in the following sentences.

(i)To look at different configurations of lightshelves as an effective technique that can be used to enhance natural lighting in offices. (ii) Assess the energy savings (direct and indirect) that could be achieved by employing light shelves into different deep plan office alternatives. (iii) Investigate into what makes a good daylight design, and what could be reliable. (iv) Suggest better ways to input an interface between daylighting and artificial lighting during non-occupancy hours when lights will be switched of completely while keeping in mind energy consumption levels.

\section{LIGHT SHELF SYSTEM PARAMETERS}

Light shelves position and placement may vary depending on the required demands, in which it may be external or internal, or even placed at both areas. The ultimate goal is to use lightshelves as a strategy which can help illuminate deeper into office spaces, yet at the same time at a controlled brightness level, within the occupants fields of vision. It is important to consider various implications that can have a great significance on daylighting design strategies. Utilizing all-glass facades in buildings is a way to help improve the quality of lighting in the indoor environment, however varying temperatures from the exterior environment limits such use.

Having attained a deeper understanding of light shelves, it is important to summarize the advantages and disadvantages of using light shelves before considering their best and suitable ways of use. Assessing light shelves as part of innovative systems could decrease energy loads, as well as enhance lighting deeper into the office spaces. Light shelves are placed internally and externally, to make an effort to penetrate most light into spaces without glare and discomfort.

\subsection{Variables Affecting Light Shelf Performance}

Because a light shelf can function to block the direct sun and help increase daylight levels deep within a room, there is a need to find a balance between how much light to block at the front of room and how much light to direct into the rear of room. Variables affecting the performance include light shelf mounting height, geometry, building orientation, location, material and the climate conditions effect on light shelf.

\subsubsection{Lightshelf Mounting Position}

External light shelves could redirect more daylight and work as overhang devices. Light shelves could locate inside or outside or on both sides of a building facade. Internal light shelf blocks less daylight, and it usually redirects less daylight into buildings. Combined light shelves could utilize the advantages of both and provide the most evenly distributed illumination. Light shelves often require high ceilings in a room. This is because a light shelf mounted below eye-level will reflect sunshine directly to peoples eyes. Lower light shelf could also block peoples visibility of exterior view, reduce ceiling height visually and make people near window uncomfortable. Figure 2 shows different possible models of light shelves which can be used to provide uniform daylight in a room.

The different models are indicated from Case 1 to Case 5 and are discussed below.

Case 1 represents a at light shelf which is completely inside a room starting at a window. It is named as 'Internal light shelf' in Figure 2(a). The same is also indicated as 'Int' in Results section of this article.

Case 2 represents a at light shelf which is completely outside a room starting at a window. It is named as 'External light shelf' in Figure 2(b). The same is also indicated as 'Ext' in Results section of this article.

Case 3 represents a light shelf in which half of the length is at and inside a room. The other half is outside the room and tilted at an angle from the inside half. It is named as 'Internal \& angled external light shelf' in Figure 2(c). The same is also indicated as 'Int+Ext at $\boldsymbol{\theta 0}$, in Results section of this article, where $\boldsymbol{\theta} 0$ represents the tilt angle of the light shelf in the outside with respect to the at light shelf plane.

Case 4 represents a light shelf in which half of the length is at and outside a room. The other half is also outside the room but is tilted at an angle from the other half. It is named as 'External at \& angled light shelf' in Figure 2(d). The same is also indicated as 'Ext half at $\boldsymbol{\theta 0}$, in Results section of this article.

Case 5 represents an angled light shelf which is at a distance from a window. It is named as 'Externally hanging angled light shelf' in Figure 2(e). The same is also indicated as 'Hang at $\boldsymbol{\theta 0}, \mathrm{d} \mathrm{mt}$ ' in Results section of this article, where $\mathrm{d} \mathrm{mt}$ is the distance of the light shelf from the window in meters. 


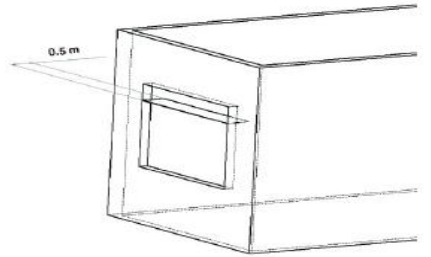

(a) Case 1. Internal light shelf

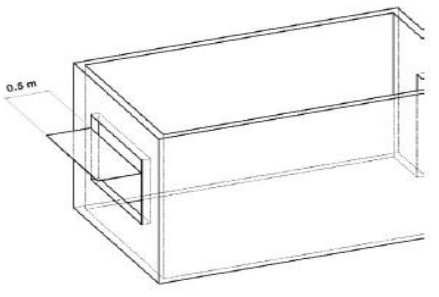

(b) Case 2. External light shelf

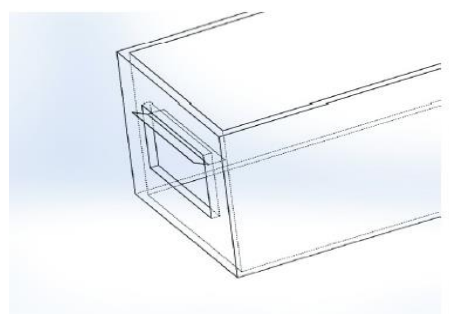

(c) Case 3. Internal \& angled external light shelf

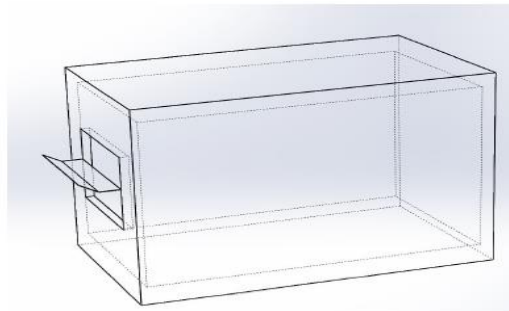

(d) Case 4. External flat \& angled light shelf

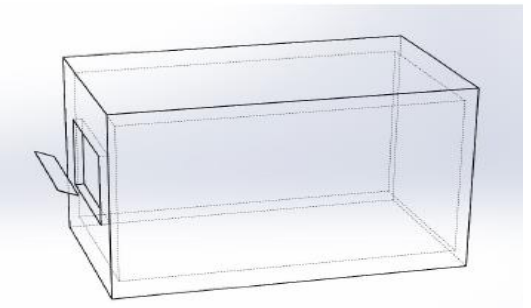

(e) Case 5. Externally hanging angledlight shelf

Figure 2. Different possible cases to analyze suitable configuration of light shelves

\subsubsection{Ceiling Effects}

The ceiling slope is another important characteristic. Freewan et. al. [8] tested a room with a fixed light shelf and compared the four different ceiling geometries: at ceiling, curved ceiling, chamfered and sloped ceiling on their effect of daylight performance of the test room.

\subsubsection{Material, Climate, Building Orientations and Location}

Most light shelf products are made of opaque materials. The solid geometry blocks direct sunshine and prevents glare in areas near windows while the high reflectance surface reflect lights into deeper part of rooms. Climate is a key question when considering light shelf applications. Light shelves may not be suitable for all climates. To make a light shelf function properly, it should be designed specifically for each climate, latitude and window orientation.

Light shelf position and configuration will have significant effects on light shelf performance. But more research on the combined effects of these factors should be conducted. The characteristics of a light shelf that affect its lighting performance include its type, angle, height and width. Simulation parameters in DIALux analysis were set to specific values as shown in Table 1.

Table 1. DIALux Analysis Parameters

\begin{tabular}{cccccc}
\hline Location & Orientation & Room Dimension & Time & Condition & Type \\
\hline $\begin{array}{c}\text { Bhubaneswar latitude, 20.25 } \\
\text { and longitude, }-85.83\end{array}$ & South facing & 3mt x 5mt x 2.8mt & March 21 & CIE Overcast/ & Illuminance \\
Clear Sky & (Lux) \\
\hline
\end{tabular}

\section{DIALUX}

Recent studies on light shelf have incorporated various technologies to improve efficiency. Among those technologies, the angle of the light shelf is an important element that determines efficiency. Thus, a detailed verification is performed on an office building by using DIALux lighting simulation tool. Performance is evaluated and its effectiveness is verified through a scaled prototype.

\subsection{Material Paramters and Material Speifications}

Other study space dimensions of the room under consideration are shown in Table 2. Various types of materials were used in the study space model in DIALux analysis. Table 3 shows the list of elements, area covered by the elements, and their reflectance values that are analyzed in this study. 


\section{RESULTS AND DISCUSSIONS}

Based on the parameters and specifications given in section 4.1, DIALux simulations are conducted for different possible cases discussed in Section 3 to analyze suitable configurations. Illuminance values for some of the cases are measured from a developed prototype.

Table 2. Study Space Dimensions

\begin{tabular}{cc}
\hline Type & Dimensions \\
\hline Floor area & $15\left(m t^{2}\right)$ \\
Light shelf area & $0.9\left(m t^{2}\right)$ \\
Working plane level & $0.85(m t)$ \\
Lintel level & $2.1(m t)$ \\
Window height & $1.25(m t)$ \\
Window width & $1.8(m t)$ \\
\hline
\end{tabular}

Table 4 shows the simulation results for the different cases indicated in Figure 2. Simulations convey the daylight values $(D L)$ with units in lux at $9 \mathrm{am}$, noon and $3 \mathrm{pm}$. Simulation results of Table 4 indicate that maximum daylight is available without light shelves. Daylight values in afternoon are lower than those in morning and noon because daylight does not fall on the window directly in the afternoon for the simulated room orientation and location. It is observed that at all times of day, light shelves as given in the four cases are able to reduce the amount of daylight entering the room. From Table 4, comparison of and Case 4 shows that a tilt angle of $10^{\circ}, 15^{\circ}, 20^{\circ}$ and $25^{\circ}$ slightly increases the daylight illuminance in the room.

Table 3. Study Space Dimensions and its Reflectance

\begin{tabular}{ccc}
\hline Element & Area & Reflectance \\
\hline Wall & $15\left(m t^{2}\right)$ & $50(\%)$ \\
Ceiling & $0.9\left(m t^{2}\right)$ & $70(\%)$ \\
Floor & $0.85(m t)$ & $20(\%)$ \\
Light Shelf & $1.8(m t) \times 0.5(m t)(\mathrm{W} \times \mathrm{D})=0.9\left(m t^{2}\right)$ & $90(\%)$ \\
\hline
\end{tabular}

Figure 4 shows the simulation result obtained from DIALux for the investigated room without using a light shelf in case of CIE overcast sky at 9 am. Lux values corresponding to the middle row of Figure 4 are noted and analyzed in the tabulated results. Table 5 shows the daylight intensity at specific grid points (G1 to G8) of a room. It is observed that maximum daylight is available in the room for when light shelf is not used. In Case 4, internal with external light shelf at tilt angles of 100 or 200 gives better illuminance except at grid $\mathrm{G} 1$.

A scaled prototype of the simulated room is setup using plywood. The prototype is scaled at a ratio of 1:15 with respect to the simulation model to validate the obtained simulation results. Considering the room dimensions given in Table 1, the prototype room dimensions are $0.2 \mathrm{mt} \times 0.33 \mathrm{mt} \times 0.19 \mathrm{mt}(\mathrm{W} \times \mathrm{D} \times \mathrm{H})$. A luxmeter is used to measure the illuminance levels in the prototype. Measurements were taken in an intermediate sky condition. Window size and representation of the room under consideration as shownin Figure 3 and A photograph of the implemented prototype is shown upside down in Figure 5 (a) to indicate mirrored roof and light shelf as shown in Figure 5(a).

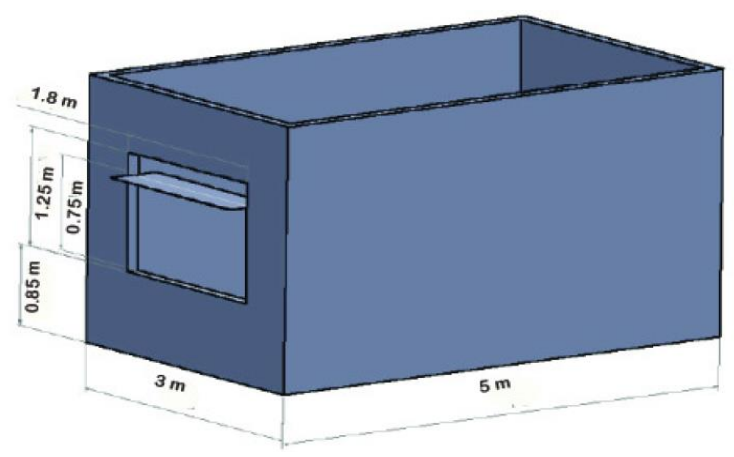

Figure 3. Window size and representation of the room under consideration 
Table 4. Study Space Dimensions and its Reflectance Simulation Performance of Light Shelf on Investigated Room at G8

\begin{tabular}{|c|c|c|c|}
\hline Investigated Room & $\begin{array}{c}\text { Morning }(9 \mathrm{am}) \\
D L(\operatorname{lux})\end{array}$ & $\begin{array}{c}\text { Noon } \\
D L(\operatorname{lux})\end{array}$ & $\begin{array}{c}\text { Afternoon }(3 \mathrm{pm}) \\
D L(\mathrm{lux})\end{array}$ \\
\hline Without Light shelf & 99 & 120 & 72 \\
\hline Case 1 (Int) & 86 & 105 & 63 \\
\hline Case 2 (Ext) & 82 & 100 & 60 \\
\hline Case $4\left(\right.$ Int + Ext at $\left.10^{\circ}\right)$ & 88 & 109 & 65 \\
\hline Case 4 (Int+Ext at $\left.15^{\circ}\right)$ & 69 & 109 & 65 \\
\hline Case $4\left(\right.$ Int + Ext at $\left.20^{\circ}\right)$ & 89 & 108 & 65 \\
\hline Case 4 (Int+Ext at $\left.25^{\circ}\right)$ & 87 & 106 & 64 \\
\hline Case $4\left(\right.$ Int + Ext at $\left.30^{\circ}\right)$ & 86 & 104 & 63 \\
\hline
\end{tabular}

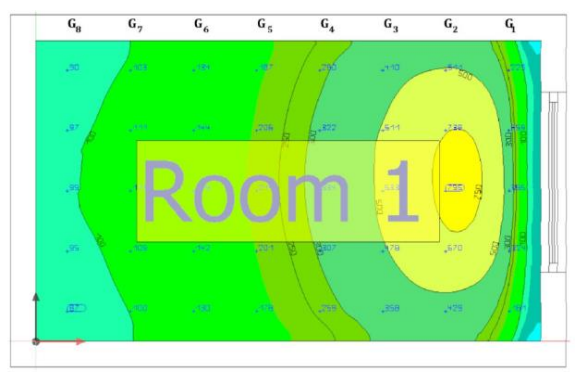

Figure 4. Simulated grid point display of the analysed room at 9 am for CIE overcast sky without light shelf

Table 5. Simulation Performance of Light Shelf on Grid Points of Investigated Room for CIE Overcast Sky

\begin{tabular}{ccccccccc}
\hline Investigated Room & \multicolumn{9}{c}{ Morning Time DL(lux) on grid points } \\
& G1 & G2 & G3 & G4 & G5 & G6 & G7 & G8 \\
\hline Without Light shelf & 225 & 544 & 410 & 280 & 187 & 134 & 103 & 90 \\
Case 1 (Int) & 230 & 506 & 373 & 240 & 155 & 112 & 87 \\
Case 2 (Ext) & 189 & 283 & 271 & 204 & 146 & 108 & 85 & 74 \\
Case 4 (Int+Ext at $10^{\circ}$ ) & 88 & 372 & 279 & 240 & 154 & 116 & 91 & 80 \\
Case 4 (Int+Ext at $20^{\circ}$ ) & 98 & 357 & 281 & 214 & 156 & 117 & 92 \\
\hline
\end{tabular}
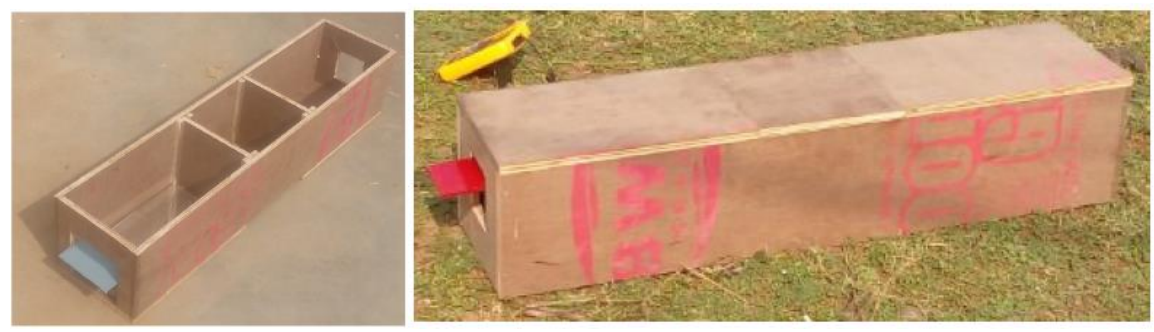

Figure 5(a). Actual image of implemented prototype (upside down). (b)Prototype with external light shelf

Figure 5 (b) is photograph of implemented prototype using for external light shelf (Case 2). In prototype, we are using a glass mirror as light shelf. One side of the glass is coated with red paint to restrict transmission of light to other side of the glass. Light rays falling on the mirror are reflected to desired area on the roof from where the light is reflected to the interior of the room.

\subsection{External Light Shelf Positioning}

Assuming a height of $1.8 \mathrm{mt}$ for inhabitants of a room, mounting position of an external light shelf is varied from $1.5 \mathrm{mt}$ to $1.8 \mathrm{mt}$. Figures 2(d) and 2(e) show two different configurations of external light shelf experimented with varying angles to maximize daylight at G8. Figure 2(d) indicates an external light shelf in which half of the shelf is connected perpendicular to the window, and the further half of the shelf is tilted at an angle with the perpendicular shelf. Figure 2(e) indicates a tilted external light shelf which is positioned at a distance from the window. An iron frame is attached at the window to hold an external light shelf at various tilt angles as shown in Figure 6. 

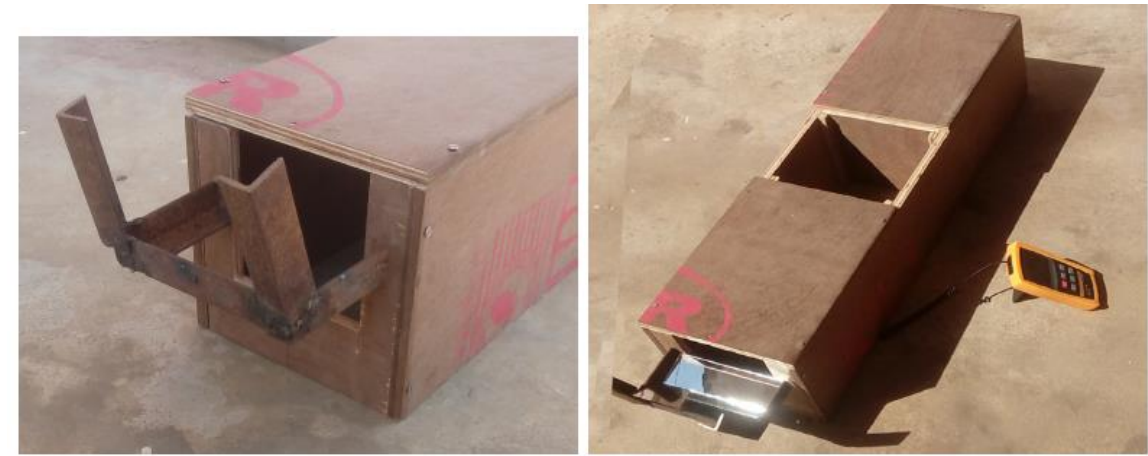

Metal frame to hold external light shelf at a height of $10.7 \mathrm{~cm}$ from ground (b) External light shelf at a height of $10.7 \mathrm{~cm}$ with reflecting mirror

Figure 6. Prototype to test external light shelf at different tilt angles

Illumination measurements for different positions of light shelf at different time instants was noted. During actual measurements it was found that the sky was clear for the day simulation results were obtained. Since the number of results obtained was large, only important data is retained in this article and results from simulation and actual measurements for similar cases are shown in same tables.

Tables 6, 7 and 8 show the simulation and measured illumination values corresponding to 9 am, 1 pm and 5 pm respectively. In these tables, the distance of light shelf from the window for Case 5 is shown as $\mathrm{d} 1, \mathrm{~d} 2$ and $\mathrm{d} 3$. Actual values of $\mathrm{d} 1, \mathrm{~d} 2$ and $\mathrm{d} 3$ from the prototype are $0.1 \mathrm{mt}, 0.15 \mathrm{mt}$ and $0.2 \mathrm{mt}$ respectively. Since the prototype is scaled down by a factor of 15 , the values of $\mathrm{d} 1, \mathrm{~d} 2$ and $\mathrm{d} 3$ in the simulations are taken as $1.5 \mathrm{mt}, 2.25 \mathrm{mt}$ and $3 \mathrm{mt}$ respectively.

Table 6. Performance of Light Shelf on Grid Points of Investigated Room at 9 Am for CIE

\begin{tabular}{|c|c|c|c|c|c|c|c|c|}
\hline \multirow{2}{*}{$\begin{array}{c}\text { Investigated } \\
\text { Room }\end{array}$} & \multicolumn{4}{|c|}{ Simulated $D L(\operatorname{lux})$} & \multicolumn{4}{|c|}{ Measured $D L(\operatorname{lux})$} \\
\hline & $\mathrm{G}_{1}$ & $\mathrm{G}_{4}$ & $\mathrm{G}_{7}$ & $\mathrm{G}_{8}$ & $\mathrm{G}_{1}$ & $\mathrm{G}_{4}$ & $\mathrm{G}_{7}$ & $\mathrm{G}_{8}$ \\
\hline Without Light shelf & 654 & 615 & 282 & 259 & 2800 & 900 & 200 & NA \\
\hline Case 1 (Int) & 4426 & 525 & 260 & 242 & 500 & 700 & 400 & NA \\
\hline Case 2 (Ext) & 3252 & 533 & 228 & 220 & 1200 & 1000 & 300 & NA \\
\hline Case $4\left(\right.$ Ext at $\left.15^{\circ}\right)$ & 2915 & 526 & 224 & 213 & 1600 & 900 & 200 & NA \\
\hline Case 4 (Ext at $\left.20^{\circ}\right)$ & 2976 & 528 & 222 & 210 & 1600 & 800 & 200 & NA \\
\hline Case $4\left(\right.$ Ext at $\left.25^{\circ}\right)$ & 3269 & 560 & 223 & 207 & 1800 & 900 & 200 & NA \\
\hline Case $4\left(\right.$ Ext at $\left.30^{\circ}\right)$ & 3099 & 525 & 216 & 202 & 1800 & 600 & 200 & NA \\
\hline Case $4\left(\right.$ Ext at $\left.35^{\circ}\right)$ & 3170 & 522 & 211 & 197 & 1800 & 500 & 100 & NA \\
\hline Case $5\left(\right.$ Ext at $\left.10^{0}, d 1\right)$ & 4557 & 659 & 279 & 267 & 4700 & 1500 & 300 & NA \\
\hline Case 5 (Ext at $\left.20^{\circ}, d 1\right)$ & 4578 & 652 & 275 & 262 & 4600 & 1200 & 300 & NA \\
\hline Case $5\left(\right.$ Ext at $\left.30^{\circ}, d 1\right)$ & 4546 & 639 & 268 & 254 & 4500 & 1500 & 300 & NA \\
\hline Case 5 (Ext at $\left.10^{0}, d 2\right)$ & 4590 & 661 & 280 & 268 & 4700 & 1300 & 300 & NA \\
\hline Case 5 (Ext at $\left.20^{\circ}, d 2\right)$ & 4585 & 657 & 275 & 262 & 4600 & 1400 & 300 & NA \\
\hline Case 5 (Ext at $\left.30^{\circ}, d 2\right)$ & 4576 & 652 & 270 & 258 & 4500 & 1200 & 300 & NA \\
\hline Case $5\left(\right.$ Ext at $\left.10^{\circ}, d 3\right)$ & 4595 & 661 & 280 & 268 & 4400 & 1400 & 300 & NA \\
\hline Case $5\left(\right.$ Ext at $\left.20^{\circ}, d 3\right)$ & 4591 & 657 & 277 & 264 & 4400 & 1500 & 300 & NA \\
\hline Case $5\left(\right.$ Ext at $\left.30^{\circ}, d 3\right)$ & 4586 & 654 & 273 & 260 & 4600 & 1400 & 300 & NA \\
\hline
\end{tabular}

Table 6 shows the illumination values from simulation results correspond ing to CIE clear sky at 9 am for different cases of light shelf positioning. Table 6 also shows actual measurements for CIE clear sky at $9 \mathrm{am}$. It is observed that at G1, maximum daylight of 4700 lux is obtained with an external light shelf (Case 5) inclined at 100 with the horizontal and placed at a distance of 0.1 to $0.15 \mathrm{mt}$ from the window. It is seen that correlation between simulation and actual results is very low, except for lux values corresponding to Case 5 at G1. The large variation in the two results is attributed to difference in parameters employed. We used mirrors in the prototype which have a reflectivity close to $99 \%$, whereas the reflectivity used in the simulations was $90 \%$ (maximum allowed by simulator) for light shelf and $70 \%$ for roof. Another factor beyond our control were passing clouds which caused very low lux values for some of the actual measurements (lux values at G1 for and Case 1). 
Table 7. Performance of Light Shelf on Grid Points of Investigated Room at 1 Pm for CIE Clear Sky

\begin{tabular}{|c|c|c|c|c|c|c|c|c|}
\hline \multirow{2}{*}{$\begin{array}{l}\text { Investigated } \\
\text { Room }\end{array}$} & \multicolumn{4}{|c|}{ Simulated $D L(\operatorname{lux})$} & \multicolumn{4}{|c|}{ Measured $D L(\operatorname{lux})$} \\
\hline & $\mathrm{G}_{1}$ & $\mathrm{G}_{4}$ & & $\mathrm{G}_{1}$ & $\mathrm{G}_{4}$ & & $\mathrm{G}_{1}$ & $\mathrm{G}_{4}$ \\
\hline Without Light shelf & 25878 & 668 & 311 & 275 & 84000 & 9800 & 1100 & NA \\
\hline Case 1 (Int) & 8666 & 545 & 266 & 261 & 31700 & 12000 & 1400 & NA \\
\hline Case 2 (Ext) & 7372 & 542 & 227 & 229 & 2500 & 14100 & 1400 & NA \\
\hline Case $4\left(\right.$ Ext at $\left.15^{0}\right)$ & 7018 & 534 & 222 & 220 & 3600 & 2900 & 600 & NA \\
\hline Case 4 (Ext at $\left.20^{\circ}\right)$ & 8090 & 570 & 233 & 231 & 3600 & 2800 & 600 & NA \\
\hline Case 4 (Ext at $\left.25^{\circ}\right)$ & 7149 & 535 & 218 & 213 & 4200 & 3900 & 700 & NA \\
\hline Case $4\left(\right.$ Ext at $\left.30^{\circ}\right)$ & 7217 & 534 & 214 & 209 & 4200 & 3800 & 700 & NA \\
\hline Case $4\left(\right.$ Ext at $\left.35^{\circ}\right)$ & 7294 & 531 & 209 & 204 & 5700 & 3300 & 600 & NA \\
\hline Case $5\left(\right.$ Ext at $\left.10^{\circ}, d 1\right)$ & 8808 & 693 & 290 & 276 & 77100 & 4600 & 900 & NA \\
\hline Case 5 (Ext at $\left.20^{\circ}, d 1\right)$ & 8835 & 686 & 285 & 271 & 82100 & 4700 & 950 & NA \\
\hline Case $5\left(\right.$ Ext at $\left.30^{\circ}, d 1\right)$ & 8798 & 672 & 278 & 263 & 82300 & 4800 & 1000 & NA \\
\hline Case $5\left(\right.$ Ext at $\left.10^{\circ}, d 2\right)$ & 8842 & 695 & 290 & 277 & 77000 & 5200 & 800 & NA \\
\hline Case 5 (Ext at $\left.20^{\circ}, d 2\right)$ & 8840 & 690 & 285 & 271 & 82000 & 4600 & 900 & NA \\
\hline Case 5 (Ext at $\left.30^{\circ}, d 2\right)$ & 8825 & 685 & 281 & 266 & 82000 & 4900 & 1200 & NA \\
\hline Case $5\left(\right.$ Ext at $\left.10^{0}, d 3\right)$ & 8848 & 695 & 291 & 278 & 77400 & 4500 & 800 & NA \\
\hline Case $5\left(\right.$ Ext at $\left.20^{\circ}, d 3\right)$ & 8846 & 691 & 287 & 273 & 5500 & 4500 & 800 & NA \\
\hline Case $5\left(\right.$ Ext at $\left.30^{\circ}, d 3\right)$ & 8844 & 688 & 283 & 269 & 76200 & 4500 & 700 & NA \\
\hline
\end{tabular}

Table 7 shows simulation results and actual measurements of daylight penetration in a room corresponding to CIE clear sky at $1 \mathrm{pm}$ for different cases of light shelf positioning. In order to find the best possible angle of light shelf, the tilt angle in simulations is varied from 100 to 350 . It is observed that with external light shelf at the window, daylight at grid points G1, G2 \& G3 is less than without a light shelf. This is attributed to light blocked by the light shelf. For the instances when the light shelf is at a distance from the window, daylight values are higher than when the light shelf is at the window. The daylight values are higher at grid points deeper in the room than without a light shelf.

It is observed that at G1, maximum daylight of 4700 lux is obtained with an external light shelf inclined at 100 with the horizontal and placed at a distance of 0.1 to $0.15 \mathrm{mt}$ from the window. The table also shows actual measurements from the prototype for CIE clear sky at $9 \mathrm{am}$. It is observed that correlation between simulation and actual results is very low, except for lux values corresponding to Case 5 at G1. The large variation in the two results is attributed to difference in parameters employed. We used a mirror in the prototype which has a reflectivity close to $99 \%$, whereas the reflectivity used in the simulations was $90 \%$ and $70 \%$ for light shelf and roof respectively. Passing clouds have caused very low lux values for some of the actual measurements

In Table 8 for Case 4 simulation results, a 200 tilt gives better illumination towards the interior of the room compared with other tilt angles. As we increase the distance of light shelf from window from $0.4 \mathrm{mt}$ to $0.8 \mathrm{mt}$, the lux value increases inside each grid point (except G1) of the investigated room. It is observed that increasing the distance of the hanging light shelf from window beyond $0.7 \mathrm{mt}$ does not increase the daylight penetration into the room.

Table 8. Performance of Light Shelf on Grid Points of Investigated Room at 5 Pm for CIE Clear Sky

\begin{tabular}{|c|c|c|c|c|c|c|c|c|}
\hline \multirow{2}{*}{$\begin{array}{c}\text { Investigated } \\
\text { Room }\end{array}$} & \multicolumn{4}{|c|}{ Simulated $D L(\operatorname{lux})$} & \multicolumn{4}{|c|}{ Measured $D L(\operatorname{lux})$} \\
\hline & $\mathrm{G}_{1}$ & $\mathrm{G}_{4}$ & $\mathrm{G}_{7}$ & $\mathrm{G}_{8}$ & $\mathrm{G}_{1}$ & $\mathrm{G}_{4}$ & $\mathrm{G}_{7}$ & $\mathrm{G}_{8}$ \\
\hline Without Light shelf & 70 & 90 & 49 & 44 & 800 & 410 & 80 & NA \\
\hline Case 1 (Int) & 510 & 90 & 43 & 43 & 250 & 125 & 90 & NA \\
\hline Case 2 (Ext) & 389 & 94 & 41 & 42 & 250 & 350 & 90 & NA \\
\hline Case $4\left(\right.$ Ext at $\left.15^{\circ}\right)$ & 344 & 93 & 40 & 41 & 300 & 340 & 100 & NA \\
\hline Case $4\left(\right.$ Ext at $\left.20^{\circ}\right)$ & 389 & 94 & 41 & 42 & 300 & 340 & 100 & NA \\
\hline Case $4\left(\right.$ Ext at $\left.25^{\circ}\right)$ & 363 & 93 & 39 & 39 & 300 & 350 & 100 & NA \\
\hline Case $4\left(\right.$ Ext at $\left.30^{\circ}\right)$ & 370 & 92 & 38 & 38 & 340 & 390 & 80 & NA \\
\hline Case $4\left(\right.$ Ext at $\left.35^{\circ}\right)$ & 380 & 92 & 37 & 37 & 320 & 330 & 70 & NA \\
\hline Case $5\left(\right.$ Ext at $\left.10^{\circ}, d 1\right)$ & 517 & 107 & 45 & 45 & 470 & 180 & 50 & NA \\
\hline Case $5\left(\right.$ Ext at $\left.20^{\circ}, d 1\right)$ & 522 & 105 & 44 & 44 & 490 & 170 & 50 & NA \\
\hline Case $5\left(\right.$ Ext at $\left.30^{\circ}, d 1\right)$ & 514 & 103 & 42 & 42 & 500 & 170 & 40 & NA \\
\hline Case 5 (Ext at $\left.10^{\circ}, d 2\right)$ & 523 & 107 & 45 & 45 & 620 & 250 & 50 & NA \\
\hline Case 5 (Ext at $\left.20^{\circ}, d 2\right)$ & 522 & 106 & 44 & 44 & 540 & 240 & 50 & NA \\
\hline Case $5\left(\right.$ Ext at $\left.30^{\circ}, d 2\right)$ & 519 & 105 & 43 & 43 & 510 & 210 & 50 & NA \\
\hline Case $5\left(\right.$ Ext at $\left.10^{\circ}, d 3\right)$ & 524 & 107 & 45 & 45 & 610 & 280 & 50 & NA \\
\hline Case $5\left(\right.$ Ext at $\left.20^{\circ}, d 3\right)$ & 524 & 106 & 44 & 44 & 620 & 260 & 50 & NA \\
\hline Case $5\left(\right.$ Ext at $\left.30^{\circ}, d 3\right)$ & 522 & 106 & 43 & 43 & 630 & 330 & 50 & NA \\
\hline
\end{tabular}


Table 8 shows simulation and actual measurements of illumination for CIE clear sky at 9 am corresponding to different cases of light shelf positioning. It is observed that at G1, maximum daylight of 4700 lux is obtained with an external light shelf inclined at 100 with the horizontal and placed at a distance of 0.1 to $0.15 \mathrm{mt}$ from the window. It is observed that correlation between simulation and actual results is low, except for lux values corresponding to Case 5 at G1. The variation in the two results is attributed to difference in parameters employed. We used a mirror in the prototype which has a reflectivity close to $99 \%$, whereas the reflectivity used in the simulations was $90 \%$ and $70 \%$ for light shelf and roof respectively. Passing clouds caused very low lux values for some of the actual measurements.

In Tables 6, 7 and 8, we observe that there is small enhancement in illumination in some grid points. We have attempted another configuration of hanging light shelf to get substantial illumination enhancement in the interiors. Figure 7 is a crude attempt to enhance the daylight illumination in the interiors. Table 9 shows the measured illumination at all grid points obtained at different times of the day.

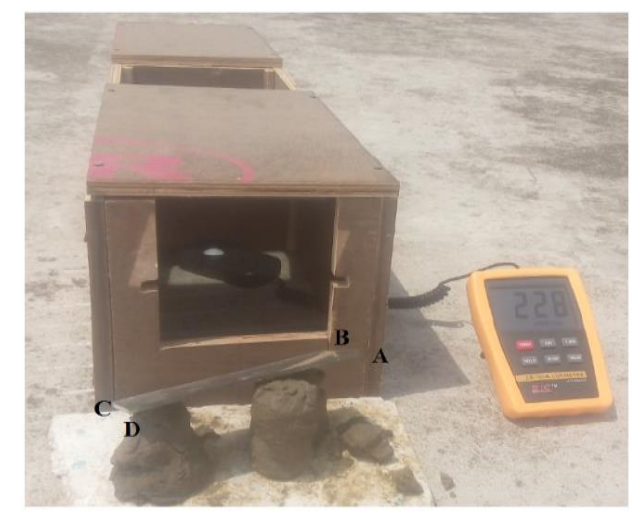

Figure 7. Mirror representation in front of prototype window

Table 9. Experiment Performance of Light Shelf on Grid Points of Investigated Room

\begin{tabular}{|c|c|c|c|c|c|c|c|}
\hline \multirow{2}{*}{$\begin{array}{c}\text { Investigated } \\
\text { Prototype Room }\end{array}$} & \multicolumn{7}{|c|}{ Time (9 am) $D L($ lux $)$ on grid points } \\
\hline & $\mathrm{G}_{1}$ & $\mathrm{G}_{2}$ & $\mathrm{G}_{3}$ & $\mathrm{G}_{4}$ & $\mathrm{G}_{5}$ & $\mathrm{G}_{6}$ & $\mathrm{G}_{7}$ \\
\hline Without light shelf & 2600 & 2200 & 1600 & 1200 & 900 & 700 & 500 \\
\hline With ext. light shelf & 4100 & 3100 & 2300 & 2200 & 2700 & 10000 & 22000 \\
\hline Investigated & \multicolumn{7}{|c|}{ Time (11 am) $D L($ lux $)$ on grid points } \\
\hline Prototype Room & $\mathrm{G}_{1}$ & $\mathrm{G}_{2}$ & $\mathrm{G}_{3}$ & $\mathrm{G}_{4}$ & $\mathrm{G}_{5}$ & $\mathrm{G}_{6}$ & $\mathrm{G}_{7}$ \\
\hline Without light shelf & 5700 & 3700 & 2200 & 1700 & 1200 & 900 & 700 \\
\hline With ext light shelf & 6300 & 4300 & 3400 & 2700 & 9100 & 12400 & 24400 \\
\hline Investigated & \multicolumn{7}{|c|}{ Time (1 pm) $D L($ lux $)$ on grid points } \\
\hline Prototype Room & $\mathrm{G}_{1}$ & $\mathrm{G}_{2}$ & $\mathrm{G}_{3}$ & $\mathrm{G}_{4}$ & $\mathrm{G}_{5}$ & $\mathrm{G}_{6}$ & $\mathrm{G}_{7}$ \\
\hline Without light shelf & 6900 & 4700 & 2400 & 1800 & 1300 & 900 & 800 \\
\hline With ext light shelf & 7300 & 5400 & 3100 & 2900 & 9600 & 25400 & 22700 \\
\hline Investigated & \multicolumn{7}{|c|}{ Time (3 pm) $D L($ lux $)$ on grid points } \\
\hline Prototype Room & $\mathrm{G}_{1}$ & $\mathrm{G}_{2}$ & $\mathrm{G}_{3}$ & $\mathrm{G}_{4}$ & $\mathrm{G}_{5}$ & $\mathrm{G}_{6}$ & $\mathrm{G}_{7}$ \\
\hline Without light shelf & 4000 & 2700 & 1500 & 1200 & 800 & 500 & 400 \\
\hline With ext light shelf & 4400 & 2700 & 1700 & 1600 & 13900 & 17500 & 16200 \\
\hline
\end{tabular}

As given in the table, we have obtained substantial enhancement of illumination at grid points G6 \& G7 and significant enhancement in all the other grid points by this directed reflection approach.

\section{CONCLUSIONS}

We have used simulations and measurements from a prototype to verify illumination performance with a light shelf in indoor environments. The results of this article is summarized in the following sentences. Light shelves improve daylight penetration with some configurations. Light shelves provide shading near the window and eliminate glare. Light shelves can improve uniformity of daylighting. This article confirms that a lightshelf can ensure great promise in terms of energy efficiency and daylight penetration into deep areas.

Some aspects on which further work can be carried out are given below. Even though the prototype gives very good results, we need to develop models to find exact positioning of light shelf which can give 
best interior environment. Throughout the study, the interior environment was considered to be a vacant office for the simulation and modeling process. However, the addition of furniture and arrangements in the space could have a different effect on the output of the study. This research could also continue in the path of testing the effect of internal materials and finishes, ceiling heights, glass material on daylight penetration. The study should look at most different reflective materials, as well as compare between them.

\section{REFERENCES}

[1] Y.-W. Lim, M. Z. Kandar, M. H. Ahmad, D. R. Ossen, A. M. Abdullah. "Building faacade design for daylighting quality in typical government office building". Building and Environment. 2012; 57: 194204.

[2] Y.-W. Lim, M. H. Ahmad. "The effects of direct sunlight on light shelf performance under tropical sky". Indoor and Built Environment. 2015; 24(6): 788-802.

[3] M. A. R. Joarder, Z. N. Ahmed, A. D. Price, M. Mourshed. "A simulation assessment of the height of light shelves to enhance daylighting quality in tropical office buildings under overcast sky conditions in dhaka, Bangladesh".

[4] D. Safa, Z. Noureddine, S. M. Yacine, "A study of optimization of the light shelf system in hot and arid zones, in: Proceedings of the Solar", 2013.

[5] M. H. Moazzeni, Z. Ghiabaklou. "Investigating the inuence of light shelf geometry parameters on daylight performance and visual comfort, a case study of educational space in tehran, iran". Buildings. 2016; 6(3): 26.

[6] A. Meresi. "Evaluating daylight performance of light shelves combined with external blinds in southfacing classrooms in Athens, Greece". Energy and Buildings. 2016; 1(16): 190-205.

[7] L. Brotas, D. Rusovan. "Parametric daylight envelope". Proceedings of the PLEA2013 - Sustainable Architecture for a Renewable Future, Munich, Germany, pp. 10-12, 2013.

[8] A. A. Freewan. "Maximizing the lightshelf performance by interaction between lightshelf geometries and a curved ceiling". Energy Conversion and Management. 2010; 51(8):1600-1604.

[9] G. Kim, H. S. Lim, T. S. Lim, L. Schaefer, J. T. Kim. "Comparative advantage of an exterior shading device in thermal performance for residential buildings". Energy and buildings. 2012; 46: 105-111.

[10] Gago, T. Muneer, M. Knez, H. Koster. "Natural light controls and guides in buildings. energy saving for electrical lighting, reduction of cooling load". Renewable and Sustainable Energy Reviews. 2015; 41: 1-13.

[11] A. Hashemi. "Daylighting and solar shading performances of an innovative automated reflective louver system". Energy and Building. 2014; 82: 607-620.

[12] U. Berardi, H. K. Anaraki. "Analysis of the impacts of light shelves on the useful daylight illuminance in office buildings in Toronto". Energy Procedia. 2015; 78: 1793-1798.

[13] U. Berardi, H. K. Anaraki. "The benefits of light shelves over the daylight illuminance in office buildings in Toronto". Indoor and Built Environment. 2016; 27(2): 244-262.

[14] S. Oh, H. Lee, Y. Kim. "Sa preliminary study on the evaluation of lighting performance according to the curvature and angle of light shelf". Architecture and Civil Engineering. 2014; 55: 21-24.

[15] G. Parise, L. Martirano. "Combined electric light and daylight systems ecodesign". IEEE Transactions on Industry Applications. 2013; 49(3): 1062-1070.

[16] M. Reyasudin Basir Khan, J. Pasupuleti, J. AI-Fattah, M. Tahmasebi. "Optimal grid connected pv system for a campus microgrid". Indonesian Journal of Electrical Engineering and Informatics. 2018; 12(3): 899-906.

[17] S. Kumari, S. Y. Kumar. "A novel approach of controlling the solar pv integrated hybrid multilevel inverter”. Indonesian Journal of Electrical Engineering and Informatics (IJEEI). 2018; 6(2): 143-151.

[18] B. N. Mohapatra, M. R. Kumar, S. K. Mandal, R. K. Mohapatra. "Daylight factor analysis with slat angle control for glare reduction in a three storied office building". International Journal of Applied Engineering Research. 2018; 13(15): 12040-12046.

[19] H. A. A. Wardeko. "Low cost solar energy efficiency for desalination system using simulation matlab". Journal of Telematics and Informatics. 2018; 6(1): 1-6.

[20] B. N. Mohapatra, R. K. Mohapatra. "Microcontroller based dual axis solar tracking system". MulticonW. 2015: 1-3.

[21] B. N. Mohapatra, M Ravi Kumar, Sushanta K. Mandal. "Analysis of Daylighting using Daylight Factor and Lumminance for Different Room Schenarios". International Journal of Civil Engineering and Technology (IJCIET). 2018; 9(10): 949-960. 